\title{
The Effectiveness of Organizer Sempoa (Abacuses) of Pregnant Women, Children, and Mother of Toddlers as a Media of Health Education
}

\author{
Indri Astuti Purwanti ${ }^{1 *}$ Lia Mulyanti ${ }^{2}$ Novita Nining Anggraini ${ }^{2}$ \\ ${ }^{1}$ Public Health Faculty, Universitas Muhammadiyah Semarang, Semarang City, Central Java 50273, Indonesia \\ ${ }^{2}$ Faculty of Nursing and Health Science, Universitas Muhammadiyah Semarang, Semarang City, Central Java 50273, \\ Indonesia \\ *Corresponding author.Email: ia_purwanti@unimus.ac.id
}

\begin{abstract}
The use of the Maternal and Child Health book (KIA book) as a health promotion medium to increase knowledge about stunting is considered not optimal. This encourages researchers to create media creations for organizer abacuses of pregnant women, children and mothers of toddlers. The research location is in the working area of Puskesmas Kedungtuban because it has the highest number of stunting cases among the Blora Regency Health Office. This study aims to test the effectiveness of the abacus media compared to conventional media (KIA book). This research is a quasy experiment with the equivalent control group form. The subjects of this study were 36 pregnant women in the working area of the Kedungtuban Public Health Center who had a risk of giving birth to a stunted baby as many as 36 respondents, consisting of 18 respondents from the abacus media group (treatment) and 18 respondents from the conventional media group (control). The research instrument was a questionnaire whose validity was tested by the expert judgment method. The average knowledge about stunting in the abacus media group was 14.44 before treatment and 19.11 after treatment with increased knowledge of 4.67. The average knowledge about stunting in the conventional media group was 17.22 before treatment and 19.56 after treatment with increased knowledge 2.33. The t-test result in the abacus media group was 0.000 ( $\mathrm{p}$ value $<0.05$ ) while in the conventional media group it was 0.003 ( $\mathrm{p}$ value $<0.05$ ). The result of the $t$ test (independent) which compared the increase in knowledge in the abacus media group and conventional media was 0.26 ( $\mathrm{p}$ value $>0.05$ ). There is a significant difference in knowledge about stunting based on the treatment of the abacus media. There is a significant difference in knowledge about stunting based on conventional media treatment. However, there was no significant difference in increasing knowledge based on the treatment of the abacus media with conventional media. Thus, the abacus media has an equivalent effectiveness with conventional media. We recommend that the media for organizer of pregnancy, children, and mothers of toddlers be developed to be used as a media for health promotion in the mother's class.
\end{abstract}

\section{Keywords: pregnant women class, knowledge about stunting, health education media}

\section{INTRODUCTION}

The important key to character building adolescents is parenting ${ }^{1}$. Good parenting will produce good children's character as well ${ }^{2}$. On the other hand, bad parenting will result in poor children's character, one of which is the occurrence of stunting ${ }^{3}$. The results of research in the working area of Puskesmas (Community Health Center) Kedungtuban in Blora regency in 2019 show that only $57,1 \%$ of pregnant women class participants have smartphones and the practice of caring for pregnant women to prevent stunting since the beginning of pregnancy has not been implemented properly ${ }^{4}$. This is assessed from the behavior of taking supplements and checking height, upper arm circumference and hemoglobin levels that are not done before pregnancy. According to data from the Blora District Health Office, Kecamatan Kedungtuban has the highest incidence of stunting 5 .

Parenting practices are part of health behavior. This health behavior is influenced by education, knowledge and experience as predisposing factors, namely factors that are inherent in a person ${ }^{6}$. Education for improving parenting practices is not general education consisting of primary, secondary and tertiary education, but education for pregnant women. Pregnant women class aims to increase knowledge and the health education media used in the class of pregnant women according to the minimum 
standards of the Indonesian government are maternal and child health book (KIA book) ${ }^{7}$.

There is a relationship between the use of the KIA book and the level of knowledge and health behavior of pregnant women in the third trimester, the higher the use of the KIA book, the higher the level of knowledge and health behavior of pregnant women ${ }^{8}$.

Unfortunately, the KIA book has weaknesses. Duplication of data occurs frequently, data cannot be continuous, there was a recording error, and it took a long time to find data, also took a long time to compile a report, so that an information technology-based e-health application was created ${ }^{9}$. This application requires an internet network to use it. Even though not all pregnant women class participants have smartphones. This e-health application is also not intended to solve stunting problems.

Researchers created an organizer sempoa (abacuses) of pregnant women, children and mothers of toddlers. This abacuses consists of two sides. The first side contains the risk factors for giving birth to a stunted baby (birth length less than $48 \mathrm{~cm}$ ). This first side can be used by pregnant women or expectant mothers. Every time the mother has one risk factor, then she has to shift one abacus seed. The more abacus seeds are moved, the higher the risk of pregnancy for the mother. The first side also features a minimum fetal length when examined by ultrasonography (USG).

The second side contains reminders of the types of nutrients at certain meal times and certain groups. There is a group of pregnant women, postpartum mothers, babies 06 months, babies 6-9 months, babies 9-12 months, and children 1 year or older. The second side is also equipped with a minimum body length or minimum height from birth to 2 years of age.

Five experts have been asked to evaluate this tool. As many as 4 out of 5 experts stated that the abacus was more attractive than books. The fourth reason is that the interest in the abacus arises by its simple, informative and colorful design. When viewed from the practicality aspect of the tool, all experts / experts agree that 5 out of 5 experts agree that the abacus is more practical than conventional tools but 1 in 5 experts state that books are still needed as a more detailed companion. However, 3 out of 5 experts stated that they could not yet assess the effectiveness of the tool because the tool had not been tested. All three suggested that there should be a comparative test between the groups that were facilitated by the tool and those that were not facilitated first to assess the effectiveness of the tool. This study aims to test the effectiveness of the abacus media compared to conventional media (KIA book).

\section{METHOD}

This research is a quasy experiment with the equivalent control group form. The subjects of this study were 36 pregnant women in the working area of the Kedungtuban Public Health Center who had a risk of giving birth to a stunted baby. The population of this study were all pregnant women in the working area of Puskesmas
Kedungtuban. The sample size required for this study was calculated using the Frederer formula because the research was conducting an experiment

Frederer's formula is:

$(\mathrm{t}-1)(\mathrm{n}-1) \geq 15$

Information:

$\mathrm{t}=$ number of repetitions / experimental group

$\mathrm{n}=$ number of samples required

This study used 2 repetition groups, namely the control group (KIA book, the conventional tools) and the experimental group (the abacus media tools). The sample calculation result based on this formula is 16 . Thus, the minimum number of samples for the control group was 16 pregnant women and the number of samples for the experimental group was also at least 16 pregnant women. Researchers took a sample of 18 respondents for each group. So, there are the number of respondents in this study are 36 people consisting of 18 respondents from the abacus media group (treatment) and 18 respondents from the conventional media group (control).

The research instrument was a questionnaire whose validity was tested by the expert judgment method. Data analysis was performed using univariate analysis and bivariate analysis. Univariate analysis used mean, median, standard deviation and variance because the research data is in the form of numbers. Bivariate analysis used the independent sample t-test because the data is normally distributed (table 1).

Table 1. Normality Test Results

\begin{tabular}{|l|l|l|}
\hline Knowledge Variable & P value & Interpretation \\
\hline Knowledge before intervention & 0,336 & Normal data \\
\hline Knowledge after intervention & 0,400 & Normal data \\
\hline Increased knowledge & 0,290 & Normal data \\
\hline
\end{tabular}

\section{RESULT AND DISCUSSION}

The knowledge data on each of these tools was tested by ttest (paired), while the increase in knowledge between the abacus tool and conventional tools was tested by t-test (independent).

Table 2. T-Test Results (Paired) Based on Abacus Tools and Conventional Tools

\begin{tabular}{|l|c|c|c|}
\hline Type of tool & $\begin{array}{l}\text { Mean before } \\
\text { intervention }\end{array}$ & $\begin{array}{l}\text { Mean after } \\
\text { intervention }\end{array}$ & P value \\
\hline Sempoa & 14,44 & 19,11 & 0,000 \\
\hline Conventional & 17,22 & 19,56 & 0,003 \\
\hline
\end{tabular}

The test results indicate that there is a significant difference in knowledge before and after the intervention 
with the abacus tool. The average knowledge about stunting in the abacus media group was 14.44 before treatment and 19.11 after treatment. The test results also show that there are significant differences in knowledge before and after intervention with conventional tools. The average knowledge about stunting in the conventional media group was 17.22 before treatment and 19.56 after treatment (table 2).

Table 3. T-Test Results (Independent) Based on Abacus Tools and Conventional Tools

\begin{tabular}{|l|c|c|c|}
\hline Variable type & $\begin{array}{l}\text { Abacus Tool } \\
\text { Average }\end{array}$ & $\begin{array}{l}\text { Conventional } \\
\text { Tool Average }\end{array}$ & P value \\
\hline $\begin{array}{l}\text { Increased } \\
\text { Knowledge }\end{array}$ & 4,67 & 2,33 & 0,264 \\
\hline
\end{tabular}

Increased knowledge of abacus tool is 4,67 while conventional tool increased knowledge 2,33. However, there was no significant difference in increasing knowledge based on the treatment of the abacus media with conventional media (Table 3). Thus, the abacus media has an equivalent effectiveness with conventional media.

This abacus is a visual medium. Abacus makes it easier for humans in terms of mathematics. The assessment of risk factors for pregnancy is also an application of mathematics. Unfortunately, only health professionals understand this risk factor assessment for pregnancy. Converting an abacus into a health education medium about the determinants of stunting has been proven to help increase the knowledge of pregnant women in the community.

Research on the use of the abacus as a medium for mathematics education has been widely carried out. The implementation of the abacus learning model can improve the second grade students score of Elementary School Kebraon II Surabaya, Indonesia up to $86.66 \%$ and can raise the learning achievement process as "Good" criteria between teachers and students ${ }^{10}$.

The abacus involves not only the sense of sight but also the sense of touch. Although the abacus is a visual media, this tool can be used well on students who have visual impairments ${ }^{11}$. Someone who has a kinesthetic learning method can also make good use of the abacus.

\subsection{Related Work}

The factors that influence the incidence of stunting in the working area of the Puskesmas Kedungtuban are Low Birth Weight (LBW) history, history of exclusive breastfeeding, history of complementary feeding, maternal age at pregnancy, maternal gestational age, maternal height, father's height, maternal nutritional status at pregnancy, birth spacing, mother's educational status and history of Acute Respiratory Infection (ARI) ${ }^{12}$. Audiovisual education is proven to increase the knowledge of pregnant women about stunting ${ }^{13}$. Health education on exclusive breastfeeding, which is one of the determinants of stunting, is more effective with multimedia than face-toface $^{14}$.

\subsection{Our Contribution}

The contribution of this research is to create a new tool that has at least the same effectiveness as the KIA book. KIA book can only be used one time per pregnant while abacus tool can be used multiple times by pregnant women vary even passed between generations. Book printing is also less environmentally friendly. Thus, this tool is cheaper, durable, and environmentally friendly.

\section{CONCLUSION}

Abacus organizer of pregnant women, children and mother of toddler equal effectiveness by KIA book. This tool can be developed as an audiovisual media too through further research. The most important thing in the development of this tool is to ensure a low price, durable and environmentally friendly. We recommend that the media for organizer of pregnancy, children, and mothers of toddlers be developed to be used as a media for health promotion in the mother's class.

\section{ACKNOWLEDGMENT}

This work was supported by Regional

Development Planning Agency (Badan

Perencanaan Pembangunan Daerah/BAPPEDA)

Blora Regency.

\section{REFERENCES}

\footnotetext{
${ }^{1}$ A.N. Utami, N. Hermawati, A. Alfiasari. Pengasuhan Orangtua yang Seimbang sebagai Kunci Penting Pembentukan Karakter Remaja. Jurnal Pendidikan Karakter tahun VI no.1 April 2016. DOI: https://doi.org/10.21831/jpk.v0i1.10727
}

${ }^{2}$ S. Pertiwi. Pola Pengasuhan untuk Mengembangkan Karakter Anak (Studi Kasus di Yayasan Rajawali Kota Semarang). Journal of Non Formal Education and Community Empowerment Vol.3 No.1 (2014). https://journal.unnes.ac.id/sju/index.php/jnfc/articl e/view/3921

${ }^{3}$ Tim Nasional Percepatan Penanggulangan Kemiskinan (TNP2K). 100 Kabupaten/Kota Prioritas untuk Perlakuan Anak Kerdil. Sekretariat Wakil 
Presiden Republik Indonesia. Tahun 2017.

www.tnp2k/go.id/downloads/100-kabupatenkotaprioritas-untuk-intervensi-anak-kerdil-stunting-volume$\underline{2}$

${ }^{4}$ Purwanti, I.A., Mulyanti, L., Anggraini, N.A. Praktik Pengasuhan oleh Ibu Hamil untuk Pencegahan Stunting Sejak Awal Kehamilan. Prosiding Seminar Nasional Kesehatan Tahun 2019: "Optimalisasi Pembangunan SDM Kesehatan dalam Upaya Akselerasi Penurunan Angka Kematian Ibu di Era Disrupsi”, ISBN : 978-6237123-31-6, Fakultas Ilmu Keolahragaan, Universitas Negeri Semarang, halaman 55-65. Semarang, 17 November 2019. http://ikm.unnes.ac.id/wpcontent/uploads/2020/01/Prosiding-Seminar-NasionalKesehatan-2019-HIMA-Jurusan-IKM.pdf\#page=61

${ }^{5}$ Dinas Kesehatan Kabupaten Blora. Jumlah Kasus Stunting per Kecamatan. Tidak diterbitkan. 2019.

${ }^{6}$ Green, L.W., dan Kauter, M. Health Promotion Planning: A Educational and Environmental Approach. United State : Mayfield Publishing Company. 1991.

${ }^{7}$ Kementrian Kesehatan Republik Indonesia. Pedoman Pelaksanaan Kelas Ibu Hamil. 2014. http://kesga.kemkes.go.id/images/pedoman/Pedoman\% 20Pelaksanaan\%20Kelas\%20Ibu\%20Hamil.pdf

${ }^{8}$ N.H. Ainiyah. Hubungan Pemanfaatan Buku Kesehatan Ibu dan Anak (KIA) dengan Tingkat Pengetahuan dan Perilaku Kesehatan Ibu Hamil Trimester III di Puskesmas Jagir Surabaya. Tesis. Universitas Aisyiyah Yogyakarta (Unisa). 2017. http://digilib.unisayogya.ac.id/2418/

${ }^{9}$ Widyadara, M.A.D; Bilal, M. Aplikasi E-Health Kesehatan Ibu dan Anak Sebagai Inovasi Kota Cerdas. Indonesian Journal on Network and Security Vol.8 No.4 (2019). DOI: http://dx.doi.org/10.2311/ijns.v8i4.1606

${ }^{10}$ Anam, F; Suteja, J.R; Septianto, A; Purnomo, A; Utami, Y.P. Improving The Numeracy Mathematics Ability: The Role of Abacus Learning Model. Journal of Physics: Conference Series. https://iopscience.iop.org/article/10.1088/17426596/1594/1/012041/meta

${ }^{11}$ Amato, S; Hong, S; Rossenblum, L.P. The Abacus: Instruction by Teachers of Students with Visual Impairments. Sage Journal; Journal of Visual Impairment and Blindness. https://journals.sagepub.com/doi/abs/10.1177/0145482 X1310700403

${ }^{12}$ Nisa', N.S.Faktor-Faktor yang Berhubungan dengan Kejadian Stunting pada Balita USia 24-59 Bulan (Studi Kasus di Wilayah Kerja Puskesmas Kedungtuban, Kecamatan Kedungtuban, Kabupaten Blora).Digilib Unnes. https://lib.unnes.ac.id/36389/

${ }^{13}$ Arsyati, A.M. Pengaruh Penyuluhan Media Audiovisual dalam Pengetahuan Pencegahan Stunting pada Ibu Hamil di Desa Cibatok 2 Cibung Bulang. Promotor: Jurnal Mahasiswa Kesehatan Masyarakat Vol.2 No.3 (2019). http://ejournal.uikabogor.ac.id/index.php/PROMOTOR/article/view/1935.

${ }^{14}$ Hapitria, P; Padmawati, R. Efektivitas Pendidikan Kesehatan Melalui Multimedia dan Tatap Muka terhadap Pengetahuan dan Sikap Ibu Hamil tentang ASI dan Menyusui. Care: Jurnal Ilmiah Ilmu Kesehatan. https://jurnal.unitri.ac.id/index.php/care/article/view/53 $\underline{5}$ 